\title{
Keterlibatan Jemaat dalam Disiplin Gereja Berdasarkan Matius 18:15-20
}

\section{Patrecia Hutagalung}

Sekolah Tinggi Alkitab Tiranus, Indonesia

Email: petti.hutagalung@gmail.com

\author{
Diterima: 16 Januari 2020
}

Direvisi: 6 Juni 2020

Disetujui: 11 Juni 2020

\begin{abstract}
Abstrak
Salah satu penyebab tidak terlaksananya disiplin gereja adalah ketidaktahuan jemaat terhadap keterlibatannya dalam memulihkan sesamanya yang jatuh dalam dosa. Disiplin juga dianggap tidak menggambarkan kasih Allah dan hanya tugas dari seorang pemimpin jemaat. Hal ini berujung pada pembiaran sesama yang berdosa tanpa tindakan menegur sebagai upaya untuk pemulihan. Dalam kasus lain, disiplin ditegakkan tanpa dasar kasih, banyak gereja yang kelihatannya malah menjadi tempat praktek menghakimi. Menegur saudara seiman yang jatuh dalam dosa merupakan perintah langsung dari Tuhan Yesus. Ketika jemaat ambil bagian menerapkan disiplin gereja dengan prosedur yang Alkitabiah, jemaat sedang mengejawantahkan kasih Allah yang bertujuan untuk memulihkan. Artikel ini akan menjelaskan peran atau keterlibatan jemaat dalam disiplin gereja berdasarkan Injil Matius 18:15-20, dengan menggunakan metode studi pustaka yang akan meneliti sumber-sumber dari perpustakaan maupun artikel, penelitian terdahulu dan akan dilakukan kajian teologis berkaitan dengan Matius 18:15-20 sebagai landasan Alkitab dalam penelitian ini. Hasil penelitian akan mengemukakan bahwa jemaat memiliki keterlibatan khusus dalam terlaksananya disiplin gereja.
\end{abstract}

Kata-Kata Kunci: Disiplin gereja; Injil Matius; Jemaat; Keterlibatan.

\section{Abstract}

One of the reasons for the inactivity of church discipline is the congregation's ignorance of its involvement in restoring its fallen fellows. Copyright@2020; Fidei: Jurnal Teologi Sistematika dan Praktika, e-ISSN: 2621-8135, p-ISSN: 2621-8151|126 
Discipline is also considered not to describe God's love and only the task of a church leader. This results in the abandonment of fellow sinners without reproving them in an effort to heal. In other cases, discipline is established without a basis of love, many churches seem to be places of judgment. Rebuking your brethren who fall into sin is a direct command from the Lord Jesus. When the church participates in applying church discipline with biblical procedures, the congregation is manifesting God's love which aims to restore. This article will explain the role or involvement of congregants in church discipline based on the Gospel of Matthew 18: 15-20, using the literature study method which will examine sources from libraries and articles, previous research and theological studies will be conducted relating to Matthew 18:15-20 as the basis of the Bible in this study. The results of the study will reveal that the congregation has special involvement in the implementation of church discipline.

Keywords: Church; Church Discipline; Gospel Of Matthew; Involvement.

\section{Pendahuluan}

Disiplin gereja sudah dipahami oleh gereja-gereja secara konsep namun terdapat persoalan dalam pelaksanaannya yang bersifat kontekstual. Saat ini kenyataan bahwa disiplin gereja hanya mendapat sedikit perhatian baik bagi pemimpin jemaat maupun jemaat sendiri, tidak dapat diabaikan. Ada sebagian jemaat yang tidak mengambil bagian dalam pendisiplinan, karena merasa tidak memiliki otoritas seperti pemimpinnya atau hal lain jemaat tidak mengetahui perannya berkaitan dengan disiplin gereja. Wartono mengemukakan $20 \%$ jemaat tidak memiliki pengertian tentang adanya disiplin gereja. ${ }^{1}$

Ketidaktahuan jemaat akan otoritas yang dimiliki dalam hal mendisiplin berujung pada pembiaran saudaranya yang melakukan dosa, ekstremnya bagi kebanyakan jemaat, menegur dan menasihati sesama anggota gereja dianggap hanya menjadi tugas dan tanggung jawab pemimpinnya. Takaria mengemukakan, bahwa jaman sekarang ini semakin banyak orang yang acuh tak acuh untuk mengingatkan kesalahan orang lain, apabila ia menganggap bahwa hal-hal tersebut tidak berhubungan dengan dirinya. Sebagai umat Allah, jemaat

${ }^{1}$ Yosia Wartono, "Pemecahan Persoalan- Persoalan Dalam Penerapan Disiplin Gereja Periode 2000 - 2005 Dalam Lingkup Gereja - Gereja Baptis Indonesia Badan Pengurus Daerah Kediri," STIKES R.S. Baptis 3 (July 1, 2010): 36. 
belajar untuk saling mengingatkan apabila mendapati saudaranya jatuh ke dalam dosa atau menjauh dari Tuhan. ${ }^{2}$

Disiplin gereja merupakan budaya secara sistem yang diajarkan Alkitab, untuk melindungi komunitas dari dosa. ${ }^{3}$ Disiplin yang sesuai dengan terang Alkitab merupakan kebenaran yang diperintahkan oleh Tuhan Yesus, bukan sekadar untuk menelanjangi dosa, tetapi untuk melindungi komunitas gereja dari dosa. Masalah yang terjadi di ruang lingkup gereja berkaitan dengan disiplin gereja, perlu mendapat perhatian khusus, agar gereja masa kini kembali pada tradisi yang diajarkan oleh Tuhan Yesus demi melindungi komunitas dari dosa.

Gereja merupakan milik Allah sendiri, artinya setiap sistem atau aturan yang berlaku adalah mutlak berdasarkan perintah dan ketentuan Tuhan Yesus. Dalam penelitian yang dilakukan oleh Wartono berkaitan dengan disiplin gereja, ia menegaskan bahwa Gereja merupakan lembaga milik Allah yang bertanggung jawab menjaga setiap anggotanya agar mereka tidak jatuh dalam dosa, tersesat dan hilang. 4 Salah satu upaya penjagaan tersebut tentu dengan menerapkan disiplin gereja yang Alkitabiah, artinya sesuai dengan ketetapan Allah tanpa ada unsur lain, contohnya demi kepentingan manusia semata.

Abineno mengatakan jemaat merupakan satu keluarga besar di dalam Tuhan, maka sebagai anggota keluarga, jemaat yang satu melayani dan bertanggung jawab terhadap jemaat yang lain. 5 Matius 18:15-20 menjadi landasan untuk memahami bahwa otoritas jemaat dalam menasihati anggota gereja yang melakukan pelanggaran merupakan perintah yang diberikan oleh Tuhan Yesus sendiri secara langsung dalam pengajaran-Nya. Dengan kata lain jemaat memiliki keistimewaan untuk terlibat menasihati sesamanya yang jatuh dalam dosa sebagai bentuk kepeduliannya terhadap sesamanya berdasarkan Matius 18. Otoritas yang dimaksud bukan langkah untuk mendahului pemimpin gereja atau prosedur gereja dalam pelaksanaan disiplin gereja melainkan agar tidak terjadi pembiaran sesama saudara seiman yang jatuh dalam dosa di dalam gereja dan tidak kompromi terhadap dosa. Otoritas jemaat ini pun sebagai bentuk keterlibatan jemaat akan perannya di dalam menasihati anggota gereja

${ }^{2}$ Gerry C.J Takaria, "Menyelesaikan Masalah Di Antara Sesama Anggota Jemaat Berdasarkan Petunjuk Yesus Di Matius 18:15,” Koinonia 9 (2015): 23.

${ }^{3}$ Yosia Wartono, "Pemecahan Persoalan - Persoalan Dalam Penerapan Disiplin Gereja Periode 2000 - 2005 Dalam Lingkup Gereja - Gereja Baptis Indonesia Badan Pengurus Daerah Kediri," Stikes R.S. Baptis 3 July 1, 2010.

${ }^{4}$ Ibid.

${ }^{5}$ J.L.Ch Abineno, Jemaat (Kwitang Jakarta Pusat: BPK Gunung Mulia, 1983). 
sebagai bentuk kepedulian dan pemahaman yang benar tentang disiplin yang adalah bentuk kasih Allah bukan permulaan dari perpecahan. ${ }^{6}$

\section{Metode Penelitian}

Penulis menggunakan metode studi pustaka, berupa studi terhadap jurnal dan buku-buku terkait pembahasan penulis, yang kemudian dianalisa dan diuraikan dalam pembahasan. Penulis menggunakan sumber-sumber literatur yang dipaparkan dalam pembahasan untuk menjelaskan prosedur disiplin gereja dari sisi jemaat. Adapun sumber-sumber primer yang digunakan antara lain $A$ Guide to Church Discipline karya Carl Laney dan Disiplin Jemaat karya Yohanis Luni Tumanan. Argumentasi di dalamnya didukung pula dengan studi kata yang menjelaskan makna kata penting dari ayat yang disoroti. Dengan menguraikannya secara bertahap untuk sampai pada kesimpulan bahwa jemaat memiliki otoritas dalam pendisiplinan anggota gereja dalam hal menasihati anggota gereja yang melakukan pelanggaran. Tujuan artikel ini adalah memberikan penjelasan mengenai keterlibatan jemaat dalam disiplin gereja berdasarkan Injil Matius 18:15-20.

\section{Pembahasan dan Hasil}

Matius 18 berkaitan erat dengan kehidupan bermasyarakat berdasarkan pengajaran Tuhan Yesus. ${ }^{7}$ Salah satunya adalah tentang menasihati saudara seiman dalam kaitannya dengan disiplin gereja dengan kata lain apa yang harus dilakukan apabila seorang jemaat berbuat dosa. Secara prosedural langkah awal yang perlu dilakukan adalah teguran pribadi atau menasihati, hingga pengucilan sebagai bentuk disiplin apabila saudara yang melakukan dosa tidak mengindahkan prosedur awal yang telah diterapkan. Sehingga jemaat yang terlibat dalam disiplin gereja yang dimaksud adalah kaitannya dengan teguran atau menasihati sesamanya.

Injil Matius 18:15-20, menekankan bagaimana sikap murid-murid Tuhan Yesus untuk menegur saudaranya yang jatuh ke dalam dosa. Berangkat dari kisah domba yang hilang, kasih Allah diumpamakan seperti seorang gembala yang berupaya untuk mencari satu dombanya yang hilang dan bersukacita ketika menemukannya. Sikap seorang gembala tersebut adalah mencari domba yang

\footnotetext{
${ }^{6}$ Yohanis Luni Tumanan, "Disiplin Gereja Berdasarkan Injil Matius 18:15-17 Dan Implementasinya Dalam Gereja Masa Kini," Jurnal Jaffray 15 (April 2017): 31.

${ }^{7}$ David K Lowery, "Teologi Matius," in A Biblical Theology Of The New Testament (Malang: Gandum Mas, 2011).
} 
hilang dengan sungguh-sungguh dan menyelamatkannya. Pembaca diarahkan untuk memandang kisah ini sebagaimana sikap Bapa terhadap anak-anak-Nya yang berada di jalan yang salah (18:14). Bagaimana seorang gembala berupaya menemukan dombanya yang hilang dan bersukacita setelah menemukannya kembali demikian pula Allah yang tidak menghendaki satu orang pun tersesat. Kemudian pengajaran ini, dikontraskan dengan kehidupan dalam komunitas orang percaya, pada perikob selanjutnya (18:15-20).

Takaria menjelaskan tahapan-tahapan yang diberikan oleh Tuhan Yesus, dibagi dalam ayat 15-17. Tahap pertama, disebut pembicaraan pribadi (18:15). Tahap kedua, pembicaraan di depan saksi (18:16). Tahap ketiga, pembicaraan di depan Jemaat (18:17a) dan tahap keempat adalah memandang seorang yang telah melakukan dosa sebagai orang yang tidak mengenal Allah (18:17b).8 Hal ini kemudian memberikan penegasan bahwa dalam mengingatkan kesalahan saudara seiman bahkan melakukan disiplin terhadapnya harus berdasarkan kebenaran firman Tuhan.

Matius 18 disebut sebagai bentuk 'Percakapan Eklesiologis', karena menggunakan kata ekklesia yang berarti Gereja atau komunitas atau 'Percakapan mengenai Persekutuan atau Jemaat'. ${ }^{9}$ Dalam konteks ini, yang dimaksud adalah tentang menasihati sesama saudara yang kemudian berkembang sebagai landasan disiplin gereja apabila tahap-tahap awal tidak mendapat respon positif dari saudara seiman yang jatuh dalam dosa. Tidak terlalu berbeda dengan apa yang dipaparkan oleh Takaria sebelumnya, penulis mengemukakan pula bahwa ayat 15-17 menunjukkan apa yang harus dilakukan oleh orang percaya untuk menegur atau menasihati sesamanya yang berbuat dosa. Sedangkan dalam ayat 18-20 merupakan janji Allah bagi jemaat yang bersedia melakukan perintah-Nya. Penulis menjelaskan tiga ayat pertama sebagai tahapan yang harus dilakukan orang percaya untuk mengingatkan sesamanya yang jatuh dalam dosa, sesuai dengan ayat 15-17 berkaitan dengan menegur saudara yang berdosa. Pertama menegur secara empat mata, kedua menegurnya dengan membawa saksi dan yang ketiga adalah membawa persoalan yang belum selesai ke hadapan jemaat sebagai bentuk disiplin.

${ }^{8}$ Takaria, "Menyelesaikan Masalah Di Antara Sesama Anggota Jemaat Berdasarkan Petunjuk Yesus Di Matius 18:15," 25.

${ }^{9}$ David K Lowery, "Teologi Matius," in A Biblical Theology Of The New Testament, (Malang: Gandum Mas, 2011), 59. 


\section{Menegurnya Empat Mata}

Bagian ini akan membahas tahap yang pertama, yakni menegur saudara yang berdosa di bawah empat mata. Memang tidak ada penjelasan jenis dosa atau seberapa berat pelanggaran yang dilakukan menurut saksi yang pertama, namun Tuhan Yesus menganggap setiap pelanggaran merupakan hal yang serius sehingga hal pertama yang harus segera dilakukan adalah menegurnya empat mata. Tahap ini dilakukan secara diam-diam tanpa melibatkan orang lain, melainkan hanya antara dua orang saja yaitu saksi pertama dan seorang saudara yang melakukan suatu kesalahan. Dalam Alkitab Terjemahan Indonesia Seharihari dikatakan 'kalau saudaramu berdosa terhadapmu, pergilah kepadanya dan tunjukkanlah kesalahannya' (15a).

Kata tegurlah di dalam bahasa Yunani menggunakan kata " mengekspresikan suatu perintah atau nasihat yang memiliki arti expose atau 'membongkar'. Kata ' $€ \lambda \in \gamma \xi o \nu$ dalam konteks ini menyatakan suatu tindakan yang dilakukan, sebagai akibat dari sesuatu yang pernah terjadi di masa lalu. Tumanan berpendapat bahwa fungsi dari saksi pertama dalam tahap ini adalah membawa saudara tersebut pada terang untuk meyakinkannya dari sesuatu. ${ }^{10}$ Artinya, orang pertama yang mengetahui bahwa saudaranya telah melakukan dosa, ia harus 'membongkar' dosa itu secara empat mata. Terjemahan lain menggunakan kata bring to light. Membawanya pada terang dan kebenaran, merupakan solusi utama yang harus dilakukan ketika mendapati saudara seiman melakukan dosa. Membawanya pada terang dan kebenaran merupakan penegasan bahwa landasan dalam prosedur ini adalah kasih Kristus. Artinya, ketika terjadi peneguran oleh saksi pertama, saksi tersebut tidak sedang menghakimi atau memermalukan saudaranya melainkan ingin membawanya kembali pada terang Kristus. Mengingat bahwa prinsipnya adalah membawa saudara yang jatuh dalam dosa kembali pada terang maka, yang dimaksud dengan saksi pertama mengacu kepada orang percaya atau jemaat yang dewasa secara rohani karena sesuai konteksnya pesan ini disampaikan oleh Tuhan Yesus kepada murid-muridNya.

Dalam kaitan menasihati sesama dalam tahap empat mata, tampaknya Tuhan Yesus tidak menghendaki penundaan di sana. Artinya, ketika telah terdeteksi bahwa ada saudara yang melenceng dari kebenaran dengan bukti yang memadai, perintah Yesus adalah pergi dan tegorlah saudaramu itu. Jika mau

${ }^{10}$ Tumanan, "Disiplin Gereja Berdasarkan Injil Matius 18:15-17 Dan Implementasinya Dalam Gereja Masa Kini." 
mendengarkan apa yang telah dibongkar oleh saudaranya, dengan catatan ia mengaku dan bersedia berpaling dari dosanya pada kebenaran, maka permasalahan dianggap selesai (ay.15b). Dalam hal ini, ada harapan bahwa seorang saudara yang melakukan kesalahan akan mendengar atau kembali kepada terang. Jika ia memang mendengar dan menyadarinya maka permasalahan dianggap selesai dan saksi pertama dianggap berhasil mendapatkan saudaranya kembali. Tahap pertama merupakan teguran yang hanya melibatkan pelaku dan saksi yang pertama atau orang yang pertama kali mengetahui kesalahan saudaranya.

Tidak ada penjelasan spesifik mengenai bentuk dosa atau bentuk kesalahan yang dilakukan. Tampaknya, Yesus tidak sedang menegaskan tahap ini diberlakukan hanya untuk seorang yang melakukan kesalahan terhadap individu tertentu, melainkan murni melakukan kesalahan atau pelanggaran yang memang merugikan dirinya sendiri. Sebagaimana yang ditegaskan oleh Tumanan, "Tanggung jawab kita terhadap saudara yang berdosa, tidak dibangun melalui fakta bahwa ia telah bersalah kepada kita, tetapi oleh kenyataan bahwa ia telah berbuat dosa dan merugikan dirinya sendiri. Inilah proses awal dari pelaksanaan disiplin gereja sebagai ajaran Yesus yang didelegasikan-Nya kepada gereja mula-mula dan diteruskan hingga kini." 11

Perintah Tuhan Yesus berkaitan dengan menasihati sesama, memang bukan mengarahkan para murid melakukan proses menegur demi kepentingan pribadi, tetapi mengarahkan mereka untuk melihat pelanggaran saudaranya sebagai sebuah tanggung jawab untuk memulihkan sesamanya yang jatuh dalam dosa dan merugikan dirinya sendiri karena pelanggarannya. Tidak heran mengapa Tuhan Yesus memberikan perintah kepada saksi yang pertama untuk "pergi" kepada saudaranya yang jatuh dalam dosa dan menegor dia. Sebagaimana nasihat Rasul Paulus, bahwa sebagai yang rohani tunjukkanlah kepedulian dengan memimpin sesama yang kedapatan melakukan suatu pelanggaran untuk menolong mereka ke jalan yang benar (Gal.6:1).

Dalam pelaksanaan disiplin gereja merupakan tanggung jawab terhadap sesama saudara dalam komunitas gereja, di mana otoritas dalam hal menasihati atau menegur merupakan bagian dari peran jemaat selaku murid Kristus dengan kata lain ada keterlibatan jemaat di dalamnya. Maka, jemaat memiliki otoritas dan tanggung jawab untuk menegur ketika ia mendapati saudaranya berdosa

${ }^{11}$ Tumanan, "Disiplin Gereja Berdasarkan Injil Matius 18:15-17 Dan Implementasinya Dalam Gereja Masa Kini." 
berlandaskan teladan dari Bapa di surga yang tidak ingin satu anak-Nya hilang. Dengan kata lain, jemaat memiliki hati yang tidak ingin saudaranya terhilang.

Tetapi merupakan kekeliruan jika dalam prosedur menegur saudara seiman diterapkan karena kita memiliki rasa benci terhadap orangnya, bukan membenci dosanya. Maka dalam tahap ini, jemaat menegur sebagai bentuk kepedulian agar sesamanya menyadari bahwa apa yang ia lakukan adalah merugikan dirinya sendiri. Sebagai saksi pertama melakukan peneguran terhadap saudaranya adalah murni untuk menunjukkan kesalahannya dan membawanya pada terang atau pada kebenaran yang sesungguhnya. Inilah maksud dari perintah Tuhan Yesus dalam menegur secara empat mata. Teguran empat mata, bukan untuk kepentingan pribadi melainkan kepentingan saudara seiman yang jatuh dalam dosa, sebagai tanggung jawab dan upaya orang percaya untuk memerlihatkan kepadanya selain dosa merugikan dirinya sendiri, ia tidak ingin saudaranya hilang dari persekutuan orang percaya bahkan dikemudian hari, berpotensi mengalami disiplin yang lebih berat lagi.

Laney menyebut bagian ini sebagai Private Reproof, 12 termasuk dalam level personal atau istilah lain adalah teguran pribadi. Dalam hal ini, disampaikan suatu penegasan adanya tanggung jawab jemaat yang satu untuk memerhatikan jemaat yang lain dan tidak segan untuk saling menegur. Komunitas gereja tidak ingin saudaranya tersesat. Maka, jika terdeteksi adanya kesalahan, itulah saat yang tepat untuk mengejawantahkan kepedulian dan kasih Kristus dalam tahap peneguran empat mata. Perlu digaris bawahi, bahwa konteks sebelumnya telah menekankan kepada pembaca apa yang Tuhan Yesus mulai dengan perumpamaan domba yang hilang.

Seorang gembala saja tidak ingin satu dombanya hilang. Demikian pula Bapa, tidak ingin satu jiwa pun hilang. Ayat 15 tidak meninggalkan catatan spesifik bentuk dosa yang dilakukan, sebagaimana yang telah disinggung sebelumnya. Tetapi yang menjadi fokus adalah panggilan yang Tuhan Yesus berikan kepada orang percaya dalam komunitas gereja untuk peduli terhadap pergumulan sesamanya, khususnya dosa spiritual. Jadi dengan jelas dikatakan dalam ayat ini, jika ada saudara yang melakukan dosa, mengancam dan merugikan dirinya sendiri, maka jemaat, selaku komunitas orang percaya, harus pergi kepadanya menunjukkan kesalahan dengan menegurnya empat mata.

Takaria menjelaskan kata "saudara" sebagai bentuk penegasan yang diberikan oleh Tuhan Yesus, bahwa Tuhan Yesus tidak menghendaki jemaat

\footnotetext{
${ }^{12}$ Carl Laney, A Guide to Church Discipline (Minneapolis, Minnesota: Bethany House Publisher, 1985).
} 
untuk memandang orang yang bersalah sebagai musuh atau orang jahat, melainkan sebagai saudara. ${ }^{13}$ Ia adalah saudara yang sedang melakukan kekeliruan, maka jemaat memiliki tugas untuk mengingatkannya agar kembali kepada kebenaran. Oleh sebab itu apa yang jemaat lakukan adalah untuk mengasihi saudaranya.

\section{Membawa Dua Tiga Saksi}

'Jika ia tidak mendengarkan engkau, bawalah seorang atau dua orang lagi, supaya atas keterangan dua atau tiga orang saksi, perkara itu tidak disangsikan' (18:16). Ayat 16, ditujukan bagi orang yang tidak mendengar si penegur atau mengeraskan hati terhadap teguran saudaranya. Laney menggunakan istilah Private Conference. ${ }^{14}$ Private Conference bukan sekadar antisipasi tetapi solusi selanjutnya bagi jemaat selaku saksi dan konsekuensi bagi saudara kita yang jatuh dalam dosa, jika ia menolak untuk mendengarkan teguran sebelumnya yang bersifat empat mata. Solusi yang diberikan untuk mengatasi sikap tidak responsif dari saudara seiman yang jatuh dalam dosa tersebut adalah dengan membawa dua atau tiga orang saksi untuk menyatakan kesalahannya. Tahap ini adalah tahap selanjutnya bagi sesama yang tidak menerima teguran secara empat mata.

Saksi pertama membawa orang lain yang dipercaya untuk menegur saudara yang jatuh dalam dosa dan tidak mendengarkan teguran sebelumnya. Dua atau tiga orang saksi yang dibawa, memiliki tanggung jawab yang sama untuk menunjukkan kesalahannya, menasihati dan sampai tahap menegur saudara yang jatuh dalam dosa tersebut. Dua atau tiga orang saksi ini memiliki hati yang sama untuk membawa saudaranya yang jatuh dalam dosa tersebut kepada kesadaran akan kesalahannya dan membawanya pada terang atau kebenaran yang sesungguhnya. Tentu saja tahap ini tidak berupaya menghilangkan kasih yang ditekankan dalam peneguran empat mata. Seorang yang terbukti bersalah dan tidak mau bertobat, perlu diproses lebih lanjut. Jika teguran empat mata tidak berhasil, saksi pertama diperintahkan untuk membawa saksi yang lain sebagai tindakan yang lebih tegas ketika teguran empat mata tidak mendapat respon dari saudara yang jatuh dalam dosa. Alkitab Terjemahan Bahasa Indonesia Sehari-hari menuliskan demikian, "Tetapi kalau tidak, bawalah satu atau dua orang lagi. Sebab dalam Alkitab tertulis, 'Sekurang-

\footnotetext{
${ }^{13}$ Takaria, "Menyelesaikan Masalah Di Antara Sesama Anggota Jemaat Berdasarkan Petunjuk Yesus Di Matius 18:15," 27.

${ }^{14}$ Laney, A Guide to Church Discipline, 59.
} 
kurangnya dua atau tiga saksi diperlukan untuk menyatakan seorang tertuduh bersalah." (Mat. 18:16).

Dua atau tiga orang saksi akan memerkuat tindakan "membawanya pada terang" untuk menyatakan seorang yang tertuduh bersalah. Dalam Perjanjian Lama, satu orang saksi saja tidak berlaku untuk melakukan tindakan pemberian sanksi dihadapan TUHAN dan para imam. Sebelum orang yang berdosa dihadapkan pada imam, kehadiran dua atau tiga saksi lah yang dapat menjadi pendukung bahwa suatu kasus dapat dikatakan valid. Seperti perintah yang disampaikan Allah dan Musa menuliskan 'Satu orang saksi saja tidak dapat menggugat seseorang mengenai perkara kesalahan apa pun atau dosa apa pun yang mungkin dilakukannya; baru atas keterangan dua atau tiga orang saksi perkara itu dapat disangsikan' (Ul. 19:15). Allah menyampaikan melalui Musa, bahwa dalam penggugatan, dua atau tiga orang saksi diperlukan untuk menyatakan keabsahan suatu masalah. Anggota gereja atau jemaat yang tidak bersalah atau menjadi saksi dari suatu permasalahan memiliki hak untuk menyatakan tuduhannya dihadapan TUHAN dan para imam (Ul.19:16). Dua atau tiga orang saksi yang dimaksud, dapat memerkuat teguran terhadap seorang yang terbukti bersalah. Sehingga ada harapan bahwa anggota gereja yang jatuh dalam dosa tersebut dapat menyadari keadaan telah sampai pada situasi cukup serius untuk tujuan perubahan maupun pertobatannya.

Tuhan Yesus memberikan penjelasan bahwa, dengan adanya dua atau tiga saksi ini akan memberikan dasar yang lebih kuat dan menghindari fitnah maupun anggapan bahwa ada permasalahan internal di dalamnya, khususnya jika persoalan ini harus dihadapkan pada jemaat atau dalam lingkup yang lebih besar. Dengan demikian, keterangan yang disampaikan tidak akan disangsikan karena saksi yang ada lebih dari satu orang. Saksi-saksi tersebut adalah orang yang dapat dipercaya, dewasa secara rohani dan setiap hal yang disampaikan oleh dua atau tiga orang saksi ini adalah fakta yang dapat dipertanggung jawabkan, bukan hanya dugaan semata. Dari penjelasan ini, Tuhan Yesus menunjukkan keterlibatan pihak lain untuk menolong sesamanya. Keterlibatan pihak lain tidak kalah penting apabila saksi pertama nyatanya belum berhasil mendapatkan saudaranya kembali.

Dalam tahap ini peran atau keterlibatan jemaat tidak sedang mendisiplinnya secara publik, melainkan membawanya pada pemahaman bahwa saudara-saudaranya selaku orang percaya tidak ingin ia tersesat dan hilang. Oleh sebab itu, Tuhan Yesus memberikan otoritas kepada setiap jemaat untuk terlibat, dengan tahapan-tahapan yang ada sebagai cara untuk menolong anggota gereja 
yang jatuh dalam dosa, dengan didasarkan pada pengampunan dan itu dilakukan oleh jemaat terhadap saudara seiman yang jatuh dalam dosa dalam konteks persekutuan gereja.

\section{Membawanya ke Hadapan Jemaat}

Tahap ketiga yang Tuhan Yesus sampaikan dalam proses disiplin jemaat, Ia sampaikan dalam ayat (17), 'Jika ia tidak mau mendengarkan mereka, sampaikanlah soalnya kepada jemaat. Dan jika ia tidak mau juga mendengarkan jemaat, pandanglah dia sebagai seorang yang tidak mengenal Allah atau seorang pemungut cukai.' (Matius 18:17).

Laney membagi ayat ini menjadi dua bagian yang ia sebut Public Announcement (17a) dan Public Exclusion (17b).15 Jika apa yang disebut Laney sebagai Public Announcement tidak bekerja maka tahap akhir adalah Public Exclusion dalam ayat $17 \mathrm{~b}$, yang berarti menyampaikan persoalan kepada jemaat merupakan langkah final, yang disebut teguran publik bagi anggota gereja yang jatuh dalam dosa dan masih tidak mendengar saksi-saksi yang telah menegurnya.

Ayat 17, memberikan keterangan yang cukup jelas bahwa Tuhan Yesus sendiri telah memberikan kapasitas kepada jemaat untuk terlibat dalam pendisiplinan yang lebih besar atau disiplin sosial. Dalam ruang lingkup yang lebih besar ini, jemaat menunjukkan tanggung jawabnya kepada anggota gereja yang jatuh dalam dosa, untuk membawanya kepada terang dan memulihkannya kepada keadaan yang sesuai dengan firman Allah. Tahap ini adalah langkah yang sangat serius dan memang tidak mudah untuk dilakukan, tetapi Tuhan Yesus mengatakan bahwa ini adalah langkah yang terbaik bagi seseorang yang bersalah khususnya anggota gereja yang jatuh dalam dosa namun tetap mengeraskan hatinya.

Jemaat dalam lingkup yang lebih besar ini, berperan dalam pemulihan anggota gereja yang jatuh dalam dosa, agar tidak tersesat bahkan terhilang. Selain pemulihan, disiplin berupa teguran publik nampaknya menguatkan gereja dalam membina spiritual jemaat lain, yang turut menyaksikan tindakan yang dilakukan oleh gereja. Dengan menunjukkan sikap yang tegas terhadap perilaku dosa melalui disiplin terhadap anggota gereja yang jatuh dalam dosa, gereja sedang memerlihatkan bahwa dosa bukan suatu hal yang dapat diremehkan karena ketidakpedulian sesama jemaat, bahkan gereja. Tetapi memerlihatkan bahwa sifat tidak responsif terhadap teguran karena dosanya sendiri tidak dapat

${ }^{15}$ Ibid., 54-55. 
dibiarkan begitu saja dalam persekutuan gereja. Disiplin akan memerlihatkan bahwa Allah tidak ingin satu domba pun hilang, hal ini didelegasikan kepada jemaat dan pemimpin gereja untuk diterapkan secara nyata dalam persekutuan.

Apabila disiplin gereja diterapkan dengan tegas sesuai kebenaran, hal itu akan menjadi peringatan serius bagi jemaat yang lain, bukan untuk menakutnakuti tetapi untuk membuat jemaat memiliki pengertian bahwa dosa dan keputusan komunitas dalam pemulihan terhadap dosa bukanlah hal yang sepele. Bagi jemaat sendiri, dosa adalah hal yang serius sehingga ketika didapati anggota gereja jatuh dalam dosa, tahap-tahap peneguran dapat dilaksanakan tanpa unsur menghakimi, melainkan kepedulian sebagai orang percaya yang besar terhadap sesamanya yang jatuh dalam dosa. Jemaat akan melihat bahwa gereja bergerak untuk mengambil tindakan terhadap dosa bukan mengabaikannya tetapi gereja memiliki beban yang serupa seperti Gembala Agung yaitu tidak menghendaki satu domba pun hilang. Menyoroti kata "jemaat" yang ada dalam ayat 17 dan bagaimana Laney menjelaskan makna kata ini dalam kaitan disiplin jemaat. Kata "church" atau "ecclesia", mengacu pada pengertian bahwa jemaat memiliki suara khusus dalam tahap Public Announcement. Kata gereja merujuk pada jemaat lokal yakni orang-orang percaya, anggota gereja yang berkumpul dalam pertemuan. Yesus mengatakan bahwa hal tersebut dibawa ke hadapan jemaat sebagai bentuk pengadilan banding terakhir di dalam disiplin gereja. ${ }^{16}$

Argument ini memerlihatkan beberapa hal. Pertama, kata church memang merujuk pada pertemuan dalam "sidang atau pengadilan banding". Kata gereja adalah orang-orang percaya yang berkumpul dalam suatu pertemuan, sebagaimana yang dijelaskan oleh Laney. Laney pun menegaskan bahwa dalam tahap membawa persoalan ke hadapan jemaat atau yang ia sebut tahap Public Announcement, Tuhan Yesus merujuk pada perkumpulan komunitas orang percaya, yang dianggap mengambil keputusan dengan kesepakatan bersama atau hasil diskusi dari saksi bersama pemimpin komunitas tersebut untuk suatu keputusan bagi sesamanya yang jatuh dalam dosa.

Pemimpin jemaat memiliki peran penting, tetapi dalam hal ini jemaat juga memiliki suara yang tidak dapat diabaikan dalam pemulihan sesamanya dan menjadi saksi dengan kata lain ada keterlibatan khusus di dalamnya. Tuhan Yesus ingin jemaat memiliki beban yang sama dan kepedulian yang signifikan bagi sesamanya yang membutuhkan pertolongan, dimana beban ini tidak hanya 
dimiliki oleh pemimpinnya saja. Kendati seorang yang jatuh dalam dosa dihadapkan pada publik atau yang dikenal sebagai suatu tindakan disiplin sosial, namun sebagai tubuh Kristus jemaat tetap melakukan disiplin karena mengasihinya, bukan karena membencinya atau ingin menghakiminya. Jemaat tidak menyukai dosanya, tetapi tetap mengasihi sesamanya yang jatuh dalam dosa dan membuktikan kasih itu dalam disiplin gereja yang Alkitabiah.

Di tengah-tengah pengadilan di hadapan jemaat dan saksi mula-mula, tetap ada harapan dalam persekutuan tersebut bahwa dengan disiplin sosial ini, anggota gereja yang jatuh dalam dosa tersebut dapat menyadari keberdosaannya dan mengambil keputusan untuk kembali pada terang Allah dan dipulihkan. Dengan rendah hati kembali pada Bapa dan bersedia menerima segala konsekuensi karena tidak responsif sejak awal sehingga persoalannya harus sampai pada disiplin publik atau disiplin sosial dengan membuka kesalahannya di hadapan jemaat. Kendati demikian, disiplin gereja yang Alkitabiah tidak dapat dilepaskan dari penerimaan, maka kaitannya sangat kuat dengan pengampunan (Mat.18:21-35). Jemaat yang menjadi saksi, harus menerima saudaranya dengan tangan terbuka karena ada pengampunan disana. Oleh sebab itu bukan berarti jemaat dapat menghakimi sesamanya yang jatuh dalam dosa dengan cara semena-mena.

Tetapi jika hal ini tidak juga bekerja, jika ia tetap mengeraskan hatinya, kata Yesus 'pandanglah dia sebagai seorang yang tidak mengenal Allah atau seorang pemungut cukai.' (17b). Tahap ini dilakukan jika saudara yang jatuh dalam dosa tetap mengeraskan hatinya. Anggota gereja yang berdosa setelah dihadapkan pada jemaat, dikatakan dapat dikucilkan ketika ia memilih untuk tetap tidak mendengarkan teguran yang disampaikan. Yang terpenting tahap disiplin sosial di hadapan jemaat telah dilakukan, apabila terbukti ia tidak juga bertobat maka gereja dapat mengambil sikap yang lebih tegas lagi. Hanya saja anggota gereja tidak boleh dikeluarkan sampai dia telah diberi tahu untuk menghadap jemaat terlebih dahulu. ${ }^{17}$ Bagian ini dengan jelas menunjukkan bahwa jemaat memiliki peran tersendiri atau keterlibatan khusus, dimana jemaat diberi kapasitas bukan hanya untuk menasihati tetapi menegur bahkan menerapkan disiplin sosial sesuai dengan kapasitasnya. Jika nasihat jemaat dibawah arahan pemimpinnya itu tidak juga didengarkan, itulah saatnya untuk mengucilkan dia atau memandangnya sebagai seorang yang tidak mengenal Allah (ay.17).

\footnotetext{
${ }^{17}$ Mark Dever, 9 Marks of a Healthy Church-9 Tanda Gereja Yang Sehat (Surabaya: Momentum, 2008), 227.
} 
Dalam tahap ini, penulis berpendapat bahwa sangat baik jika gereja tidak membiarkan seseorang yang mendapatkan disiplin begitu saja, melainkan tetap memberikan ruang untuk melakukan bimbingan lebih lanjut. Dengan kata lain, seorang yang didisiplin tetap dalam pengawasan komunitas orang percaya, agar ia tidak lebih jauh lagi menyimpang dari jalan yang seharusnya. Pembinaan dilakukan dibawah bimbingan penatua, pemimpin jemaat atau orang yang dewasa secara rohani, tetapi anggota gereja yang jatuh dalam dosa tersebut tetap dalam status disiplin. Tujuannya adalah agar anggota gereja tetap dipelihara dalam proses pemulihannya. Kendati ia dalam kondisi disiplin ia tetap berbesar hati karena masih diterima. Sebagaimana yang dikatakan oleh Baker, bahwa pada kenyataannya setiap orang yang berdosa sekeras apapun hatinya, ia pasti membutuhkan cinta dan pengampunan dari keluarga gereja, ia tetap membutuhkan penerimaan dari sekelilingnya. ${ }^{18}$ Terlepas dari bagaimana respon anggota gereja yang jatuh dalam dosa, sikap gereja harus tetap mencerminkan kasih Kristus yang menerima dan ini merupakan hal penting yang perlu terus ditunjukkan oleh gereja.

Jemaat jangan sampai terjebak dalam pemikiran, bahwa disiplin gereja adalah hukuman yang setimpal atas dosa seseorang, karena itu bukanlah hak manusia. Hanya Allah yang menjadi hakim satu-satunya, yang berhak menghakimi seseorang sampai melihat setimpal atau tidak dengan perbuatan seseorang yang jatuh dalam dosa tersebut. Kasih Allah harus tetap menjadi landasan dilakukannya disiplin gereja oleh jemaat maupun pemimpin gereja. Karena disiplin dilakukan untuk kebaikan orang yang melakukan dosa dan tidak mau bertobat, bukan untuk memermalukannya.

Ada hal menarik yang disampaikan oleh Mark Dever dalam bukunya "9 Tanda Gereja Yang Sehat". Dalam kaitannya dengan disiplin gereja, Dever menganggap bahwa sebagai anggota gereja, jemaat memiliki otoritas yang telah diberikan oleh Allah untuk menghakimi. Pertama adalah diri sendiri dan kedua adalah di gereja. Hal ini bukan untuk menentang apa yang Tuhan Yesus ajarkan dalam Matius 7 tentang jangan menghakimi ${ }^{19}$ Dengan kata lain, maksud menghakimi di sana tidak dapat disejajarkan dengan apa yang Allah lakukan terhadap ciptaan-Nya. Dever kemudian menambahkan bahwa gereja yang tidak melaksanakan pendisiplinan sebenarnya telah mengaburkan Kabar Baik terlebih lagi makna hidup baru dalam Yesus Kristus.

${ }^{18}$ Don Baker, Beyond Forgiveness The Healing Touch of Church Discipline (Portland, Oregon: Multnomah Press, 1984), 53.

${ }^{19}$ Dever, 9 Marks of a Healthy Church-9 Tanda Gereja Yang Sehat. 
Penghakiman yang dilakukan dalam gereja bukan penghakiman seperti yang Allah kerjakan sebagai Hakim Agung seperti dalam Roma 13:1. ${ }^{20}$ Maka, dapat dikatakan ini bukan persoalan menghakimi secara membabi buta tanpa ampun bagi seorang anggota gereja yang jatuh dalam dosa. Menghakimi bukan untuk memermalukannya tetapi untuk menunjukkan kesalahannya dan membawanya pada kebenaran. Poinnya adalah memeringatkan supaya mendapatkan dia kembali. Oleh sebab itu, disiplin gereja sebenarnya memberikan kesempatan bagi orang percaya untuk mengejawantahkan kasih Kristus yang menebus dan memulihkan. ${ }^{21}$ Bukan semata-mata untuk hukuman yang kejam maupun ganjaran tetapi untuk memulihkan saudara seiman yang jatuh dalam dosa dimana ia sesungguhnya sedang merugikan dirinya sendiri dan membutuhkan pemulihan atas perbuatannya. Kendati demikian di dalamnya gereja pun harus tetap menampilkan ketegasan dan intoleran terhadap dosa.

Kasih yang ditampilkan bukan dimaksudkan menganggap bahwa kita lemah atau toleransi terhadap dosa, lantas menampilkan kasih Kristus yang serta merta meniadakan dosa dan mengabaikan pendisiplinan. Kasih dan penerimaan yang diberikan kepada saudara yang jatuh ke dalam dosa merupakan suatu perbuatan yang tidak dapat dilupakan, tanpa bermakna lunak terhadap dosa yang diperbuat. ${ }^{22}$ Orang percaya dalam kasihnya harus tetap menampilkan diri sebagai orang yang takut bahkan menjauhi dosa. Justru karena hal inilah Tuhan Yesus memberikan perintah agar gereja dalam persekutuannya, menerapkan disiplin gereja sesuai dengan prosedur yang diperintahkan oleh Tuhan Yesus, sebagai Pemilik gereja. Disiplin yang diberikan, jika itu sesuai dengan prosedur Tuhan Yesus, adalah disiplin berlandaskan kasih Kristus yang memulihkan. Artinya, disiplin yang berlandaskan kasih justru menunjukkan cinta dan kasih Tuhan Yesus yang mengampuni dan memulihkan. Disiplin itu dilakukan berdasarkan perintah Tuhan Yesus dan hati yang tulus untuk memulihkan saudara seiman yang melakukan dosa. ${ }^{23}$

\section{Otoritas dari Tuhan Yesus}

Matius 18:18-20 menuliskan, “Aku berkata kepadamu: sesungguhnya apa yang kamu ikat di dunia ini akan terikat di sorga dan apa yang kamu lepaskan di

${ }^{20}$ Ibid., 211.

${ }^{21}$ Laney, A Guide to Church Discipline, 57.

22 Ibid.

${ }^{23}$ Widhi Arief Nugroho, "Peranan Pendidikan Keluarga Tentang Kekudusan Hidup Menurut Roma 12:1-2,” FIDEI: Juenal Teologi Sistematika dan Praktika 1, no. 2 (Desember 2018): $185-198$ 
dunia ini akan terlepas di sorga. Dan lagi Aku berkata kepadamu: Jika dua orang dari padamu di dunia ini sepakat meminta apa pun juga, permintaan mereka itu akan dikabulkan oleh Bapa-Ku yang di sorga. Sebab di mana dua atau tiga orang berkumpul dalam nama-Ku, di situ Aku ada di tengah-tengah mereka."

Ayat 18-20 ini merupakan bukti otoritas yang diberikan oleh Tuhan Yesus secara langsung yang disertai dengan janji. Tuhan Yesus memberikan otoritas kepada jemaat untuk memulihkan sesamanya dengan persetujuan dan janji-Nya bahwa Ia turut ambil bagian. Tumanan memandang otoritas yang diberikan kepada jemaat sebagai tiga janji Tuhan Yesus tentang disiplin gereja. ${ }^{24}$ Pertama, Kristus menjanjikan bahwa apa yang telah disepakati di gereja berdasarkan Alkitab, itu juga disetujui di sorga. Maka kata Yesus apa yang diikat di bumi, itu juga terikat di sorga (ay.18). Dengan kata lain, apa yang diikat dan dilepaskan di dunia dipandang sebagai kesepakatan yang diresponi di surga.

Kedua, Kristus memberi janji tentang kesepakatan dua orang saksi, maka Bapa akan melakukannya bagi mereka. Berkaitan dengan ayat 18, ayat selanjutnya menegaskan gagasan sebelumnya, bahwa Allah yang di sorga akan mengabulkan permintaan dari dua orang yang telah bersepakat tersebut (ay.19). Dengan tegas Tuhan Yesus mengatakan bahwa Bapa di sorga turut campur tangan terhadap keputusan dari persekutuan orang percaya perihal disiplin gereja yang telah disepakati. Maka janji-Nya, permintaan mereka akan didengarkan oleh Bapa di surga yang turut ambil bagian dalam pemulihan saudara seiman yang jatuh dalam dosa.

Janji Ketiga adalah kehadiran Kristus di tengah-tengah orang yang berkumpul untuk berdoa, melakukan kesepakatan dalam hal ini untuk tujuan disiplin terhadap saudaranya yang tidak mau bertobat. Dengan kata lain, ketika dua tiga orang percaya berkumpul dalam nama Tuhan untuk mendoakan suatu pergumulan yang akan diputuskan, Allah hadir di sana. Jika janji Allah ini yang menjadi landasan jemaat, maka disiplin gereja tidak akan dilakukan dengan sembarangan. Jemaat pun selaku pihak yang terlibat akan semakin memahami tanggung jawabnya serta perannya dalam disiplin gereja. Ia, selain bertanggung jawab memerhatikan anggota gereja lainnya, sebagai jemaat, ia juga ikut mengimani janji Allah akan kehadiran-Nya dalam persekutuan gereja khususnya terhadap pemulihan saudaranya yang berdosa.

Tentu saja otoritas yang diberikan Tuhan Yesus kepada jemaat untuk ambil bagian dalam disiplin gereja, bukan semata-mata mengukur perbuatan dan

${ }^{24}$ Tumanan, "Disiplin Gereja Berdasarkan Injil Matius 18:15-17 Dan Implementasinya Dalam Gereja Masa Kini." 
ganjaran saudara seiman sebagaimana yang penulis singgung di atas. Melainkan melihat suatu hal yang lebih besar yaitu memaknai janji Allah yang ada di dalamnya. Pertama janji Allah bahwa Ia menghargai kesepakatan jemaat-Nya. Kedua, janji-Nya untuk campur tangan bahkan mengabulkan permohonan dari jemaat yang sepakat. Dan ketiga, janji Allah hadir di tengah-tengah jemaat yang bergumul. Tidak berhenti sampai di sana. Tuhan Yesus sebagai Gembala yang tidak ingin satu domba pun hilang, tetap mengarahkan jemaat untuk melihat bahwa menegur dan disiplin dilakukan dengan kasih Kristus yang memulihkan. Jemaat perlu memandang menegur sesama dan keterlibatannya dalam disiplin sebagai langkah dan tanggung jawabnya untuk mengaplikasikan kasih Allah yang memulihkan dalam persekutuan gereja. ${ }^{25}$ Secara sadar jemaat turut melakukan disiplin gereja dengan suatu keyakinan bahwa melalui disiplin gereja berdasarkan kasih Kristus membawa manusia yang jatuh dalam dosa kepada hidup yang baru. Dan jemaat sebagai tubuh Kristus, di dalam persekutuan yang kudus memiliki tanggung jawab bersama untuk melihat janji Allah ada dalam diri saudaranya yang berdosa berdasarkan kasih dan pengampunan. ${ }^{26}$

\section{Simpulan}

Jemaat memiliki keterlibatan khusus yang diberikan oleh Tuhan Yesus untuk peduli terhadap pemulihan sesamanya yang jatuh dalam dosa, bahkan Tuhan berjanji hadir di tengah-tengah mereka yang memikirkan kesepakatan dalam disiplin gereja apabila anggota gereja yang jatuh dalam dosa tidak mendengarkan teguran pribadi yang telah dilakukan. Disiplin adalah upaya gereja untuk menggambarkan kasih Allah yang tidak menyukai dosa dan tidak ingin domba-Nya hilang. Oleh sebab itu sebagai orang percaya, tidak perlu takut untuk menegur, menasihati sesama yang jatuh dalam dosa karena itu adalah upaya setiap orang percaya untuk menyatakan kasih Kristus dalam persekutuan gereja khususnya terhadap sesama yang melenceng dari kebenaran firman Allah. Sudah saatnya jemaat Tuhan turut merasakan dan ambil bagian dalam pergumulan gereja. Jemaat adalah anggota persekutuan gereja, maka jika jemaat selaku orang percaya telah menyadari keterlibatan yang diberikan oleh Tuhan Yesus, ia akan mengejawantahkannya sesuai prosedur yang Alkitabiah.

${ }^{25}$ Firman Panjaitan dan Marthin Steven Lumingkewas, "Ibadah Jemaat Kristen Kontemporer Abad 21 Dan Tinjauan Kritis Liturgis," FIDEI: Jurnal Teologi Sistematika dan Praktika 2, no. 1 (June 2019): 162-185.

${ }^{26}$ Ibid. 
Keterlibatan Jemaat dalam... (Patrecia Hutagalung)

\section{Daftar Pustaka}

Abineno, J.L.Ch. Jemaat. Kwitang Jakarta Pusat: BPK Gunung Mulia, 1983.

Baker, Don. Beyond Forgiveness The Healing Touch of Church Discipline. Portland, Oregon: Multnomah Press, 1984.

Dever, Mark. 9 Marks of a Healthy Church-9 Tanda Gereja Yang Sehat. Surabaya: Momentum, 2008.

Laney, Carl. A Guide to Church Discipline. Minneapolis, Minnesota: Bethany House Publisher, 1985.

Lowery, David K. "Teologi Matius." In A Biblical Theology Of The New Testament. Malang: Gandum Mas, 2011.

Nugroho, Widhi Arief, "Peranan Pendidikan Keluarga Tentang Kekudusan Hidup Menurut Roma 12:1-2," FIDEI: Jurnal Teologi Sistematika dan Praktika 1, no. 2 (Desember 2018): 185-198. https://doi.org/10.34081/fidei.v1i2.16.

Panjaitan, Firman dan Marthin Steven Lumingkewas, "Ibadah Jemaat Kristen Kontemporer Abad 21 Dan Tinjauan Kritis Liturgis," FIDEI: Jurnal Teologi Sistematika dan Praktika 2, no. 1 (June 2019): 162-185. https://doi.org/10.34081/fidei.v2i1.49.

Takaria, Gerry C.J. "Menyelesaikan Masalah Di Antara Sesama Anggota Jemaat Berdasarkan Petunjuk Yesus Di Matius 18:15." Koinonia 9 (2015): 23-35.

Tumanan, Yohanis Luni. "Disiplin Gereja Berdasarkan Injil Matius 18:15-17 Dan Implementasinya Dalam Gereja Masa Kini.” Jurnal Jaffray 15 (April 2017). Wartono, Yosia. "Pemecahan Persoalan- Persoalan Dalam Penerapan Disiplin Gereja Periode 2000 - 2005 Dalam Lingkup Gereja - Gereja Baptis Indonesia Badan Pengurus Daerah Kediri." STIKES R.S. Baptis 3 (July 1, 2010). 